\title{
HUMAN RESOURCES MANAGEMENT IN BRAZILIAN SUGAR AND ETHANOL MILLS: AN ANALYSIS UNDER THE CORPORATE CONTROL POINT OF VIEW
}

Roberto LOUZADA*

\begin{abstract}
This article presents the results of a survey carried out in ten sugar and ethanol mills, which were grouped into three categories: closely-held corporations, publicly-held corporations and companies controlled by an international group. The aim was to verify if the model of human resource management and corporate control revel any differentiation in the way the human resource management is conducted. The data were collected through a semi-structured interview, which was answered by the head of the Human Resources Department of the companies, allowing us to describe the practices and to identify the guiding concepts of the adopted model. Data analysis led us to conclude that the corporate control is a component that may differentiate the way human resources are managed in the mills taken as the object of this study.
\end{abstract}

Keywords: human resource management, corporate control, differentiation.

\section{ADMINISTRAÇÃO DE RECURSOS HUMANOS NAS USINAS DE AÇÚCAR EÁLCOOL BRASILEIRAS: UMA ANÁLISE DO PONTO DE VISTA DO CONTROLE SOCIETÁRIO}

\section{Resumo:}

Este artigo apresenta os resultados de uma pesquisa realizada em dez usinas produtoras de açúcar e álcool, que foram agrupadas em três categorias: capital fechado, capital aberto e controlada por um grupo internacional. Estabeleceu-se como objetivo identificar o modelo de gestão de recursos humanos e verificar se o controle societário aponta para alguma diferenciação no modo como ocorre o gerenciamento de recursos humanos. Os dados foram coletados com a utilização de um roteiro de entrevista semi-estruturados, que foi respondido pelo principal dirigente do Departamento de Recursos Humanos das usinas pesquisadas, o que permitiu descrever as práticas de recursos e identificar os conceitos orientadores do modelo adotado. A análise dos dados possibilitou concluir que o controle acionário é um dos componentes que pode diferenciar o modo como são administrados os recursos humanos, nas usinas tomadas como objeto de estudo.

Palavras-chave: administração de recursos humanos; controle societário; diferenciação.

\section{Introduction}

The sugarcane growing, as well the sugar, ethanol, and other sugarcane-related products production can be considered as an economic activity intertwined with the

\footnotetext{
* Assistant-Doctor Professor hired in a Full Teaching and Researching Regimen at UNESP Universidade Estadual Paulista - Júlio de Mesquita Filho - Jaboticabal Campus. CEP: 14.884-900. Teaches Human Resources Management I and II to Business Administration Students. Estado de Sao Paulo, Brazil, e-mail: louzada@fcav.unesp.br

Acknowledgement: A version of this article was presented in May 2013, in the VII Congress of IFBAE Instituto Franco Brasileiro de Administração de Empresa, held at Institut d'Adminstration des Entreprises - Université François Rebelais -Tours - France.
} 
economic history of Brazil. However, since early this century it is a highly modernized activity, using genetics technology to the development of new and more sucrose content varieties, which is directly reflected in the productivity indexes, turning into the sugar and ethanol national production highly competitive.

Besides, it is an economic sector that is undergoing deep changes, like some sugar and ethanol mills doing the IPO (Initial Public Offering) at BM\&FBOVESPA S. A. - Bolsa de Valores, Mercadorias e Futuros (São Paulo Stock Exchange) which creates the conditions to a concentration process through acquisitions and mergers. In addition, there are also some big international groups buying some mills, turning it into an economic activity that was traditionally controlled by Brazilian corporate groups.

Also, it is a business segment with a quite optimist growth expectation mainly due to the flex fuel technology (i.e., vehicles able to run with fuel from the petroleum and also from the ethanol or any percentage of mixture of them). To have an idea of this technology acceptance, in 2011, according to ANFAVEA - Associação Nacional dos Fabricantes de Veículos Automotores - Brasil (National Association of Automobile Producers - Brazil), the flex fuel automobile and light-truck sales were 2,848,071 units, i.e., $83.1 \%$ of the all traded vehicles.

Thus, on one hand, taking into account the mills peculiarities and its actual difficulties and on the other hand, according to the literature searched, four models of people's management - Personnel Department; Human; Strategic; and Articulated Competencies Behaviors - we could formulate the guide question of this study: does the corporate control influence the people management into the sugar and ethanol mills?

To answer this question we have decided to do a survey aiming to describe the people management practices in mills having a different shareholding control, identify the model of people management administration adopted in the surveyed mills and thus, verify if the shareholding control implies into some differentiation regarding to how people are managed.

To reach this aim, the methodological approach used to collect and analyze data about the surveyed sugar and ethanol mills is followed. After that, theoretical referential are presented to analyze the collected data and then identify the model of people management administration adopted in the surveyed sugar and ethanol mills. Further, the collected data analysis is presented into this order: sugar and ethanol mills closely-held corporations, BOVESPA publicly-held corporations, and finally the analysis about the companies controlled by an international group. The last part of the article is dedicated to the final comments.

\section{Methodology}

Due to the lack of human resources administration studies about sugar and ethanol mills, we opted to do a qualitative exploratory study, which allowed to raise a set of data about the human resources administration into this business segment.

Initially it was defined that the mills with different corporate controls should be invited to make part of this survey: closely-held corporations, publicly-held corporations and companies controlled by an international group. Out of 190 mill-controller groups in the São Paulo state, three business groups were identified in the sugarcane 2011 annual report with stocks at BOVESPA - Bolsa de Valores de São Paulo controlling 29 mills; four international groups controlling 18 mills; and 123 groups classified as closely-held, controlled by national capital. This fact allowed us to define the survey groups: two closely-held corporations, one publicly-held corporation controlling more than one sugar and ethanol mill; and a group of at least one sugar and ethanol mill controlled by an international organization. Regarding to the closely-held corporations, the contact was relatively easy and the invited corporations, 
which control the mills, accepted to be part of the survey. The same way, the corporations with stocks at BOVESPA, which control three mills, accepted to be part of the survey. The problem happened when only part of the international group (owner of $63 \%$ of the mill social capital) accepted to be part of the survey. The other part of the group, a sugarcane farmers association, did not. This sugar and ethanol mill is characterized as a joint venture and it adopts an independent administration from the international controller group, adjusting its decisions according to the group recommendations. Although this characteristic, it was understood that this group should be added to the survey as a sugar and ethanol mill controlled by an international group.

After defining the groups, data from ten sugar and ethanol mills with different corporate controls were collected, attending this way the suggested aim.

Data were collected following a semi structured interview script, answered by the main executives of human resources of each mill belonged to the survey. This tool enabled to deepen the questions according to the answers given by the respondents, in order to collect the necessary information to the desired analysis.

Having in hands the information collected, we were able to describe the human resources administration actions and guidelines in each one of the evaluated group. This information, together with the human resources policy content analysis (FRANCO, 2005), allowed us to identify the adopted human resources administration models in the surveyed mills, fitting them in the theoretical foundation, thus, verify if there is any differentiation in the people management as a function of the mills corporate control.

\section{The theoretical foundation used to analyze the collected data}

We found in the academic literature an intense debate from 1990 to 2000 about the different people managing models in the companies (EISENSTAT, 1996, IGALENS, 1999; TONELUI et al., 2002; FISCHER, 2002; MLKOVICH \& BOUDREAU, 2000). In those texts, the novelty was the discussion about a new model, still emerging, focused in a new work organization way, called by some authors Competency-based Approach.

In the 2000s, some themes come out, such Brazilian multinationals human resources administration (FISCHER \& ALBUQUERQUE, 2005; MURITIBA, at. all 2012; REIS; TONELLI; FLEURY, 2012), people management through a remote organizational structure (ALBUQUERQUE; LEITE, 2010), remaining some debates about the new people management model (DUTRA, 2007).

This thematic change may infer that the existence of four models to organize the human resource area has been consolidated during the debates occurred in the 1990's decade and early 2000, showing the existence of the following human resources area organization possibilities: Personnel Department; Human Behavior; Strategic-based, and Competency-based Approaches, according to the Fisher (2002) denomination, but other authors call then differently.

Besides, there are different analysis perspectives about how organize the human resources area. Some authors go for contextual-historic analysis (IGALENS, 1999; TONELLI et al., 2002), while others by conceptual-historic ones (FISCHER, 2002; MILKOVICH e BOUDREAU, 2000). Some others analyze the changes happened in the organizational structure using as reference the companies demand (EISENSTAT, 1996).

The first ones attempt to demonstrate an activity that originates and modifies in response to some contexts; the second ones note that the people management practice in the companies, in different periods of time, characterize as human resource management models, which are developed using scientific knowledge matrix; the last ones have as principle that the changes from a model to another happens only when the actual model no longer meets the business needs. 
Thus, this analysis will seek to highlight the theoretical premises that characterize the different conceptions of human resource management, as well to identify how they are articulated to create a management model as a coherent whole.

In this way it becomes able to be understood not only the differences between the analyses about the human resources, regard to the each organization duration, but also we believe that it will allow the several names given by the different authors surveyed.

\subsection{The First Personnel Management Model: Personnel Department}

The work conception that underlies this model is explained by Zarifian (2001, p.37) as a group of elementary activities of a matter transformation able to aim, analyze, rationalize, organize, and impose in the workshops. At that time the activities are human body gestures.

Thereby the taylorist-fordist principles, associated to the legal requirements, characterize the Personnel Department actions as personnel-control activities because both the law and the Scientific Administration fundaments have in control one of their basal elements.

Besides some disagreements among the authors regarding the period that categorizes this form of organization in the human resources area, there is a consensus that surveys carried out from 1927 to 1932 by Elton Mayo at Western Electric in Chicago mean not only a change in the personnel management way but also lays the new way of organization groundwork of this activity in the companies.

\section{(Appendix A3.1)}

\subsection{The Second Personnel Management Model: Human Behavior}

From the theoretical point of view, the great innovation is the use of concepts from the human sciences which raises the question about the economic man who guided the taylorism-fordism theoretical premises introducing the idea of social man or, as explained by Dejours (1999, p. 33),

here is the work world which is reduced to the intersubjective and social world. The physical environment and the work place demands specificity, as well the activities, in the ergonomic sense of the term, are excluded from the analysis. [...]. Regarding to the organizations psychosociology, it considers the work environment only as a concept, decorative, without any direct impact in the organization of the human behavior.

\section{(Appendix A3.2)}

\subsection{The Third Personnel Management Model: Strategic}

It is a factor in which the company, to reach its goals, is presented as almighty and installs the certainty to offer to the worker, at the same time, a statute and a adequate role to its dynamism and submission, and an intellectual and behavioral knowledge which encourages the domain of both him/ herself and the things, as well the circumstances adapting. Doing it, according to Enriquez (2001, p. 21), it tends to childish the worker, whatever claims otherwise.

\section{(Appendix A3.3)}

\subsection{The Fourth Personnel Management Model: Competency-based Approach}

The fourth human resources area organization basic features begin to set on two fronts: the debate between specialists and the companies. In the first, the attempt is to build a new model based on the strategy notion with the purpose of creating more flexible management 
able to absorb fast changes, the external environment fluidity and uncertainties. In the second, the fragmented structure predominant in the anterior model and the introduction of a decentralization process from the human resources functions to the line managers.

In the theoretical context, the strategy notion, which according to Porter (2003, p.111), being different, is linked to the competitive advantage that, according Prahalad \& Hamel (2003, p.59), are surrounding individuals whose efforts are not narrowly focused, to this people recognize the opportunities to combine their technical capacities with the others from new and interesting ways. In this case, as explained by Barbosa (1999, p.125),

It is about you take the difference as a competitive advantage. It implies in built intentionally a differentiated organization in human resources terms, with individuals from different ethnic religious, geographic, and intellectual origins to this diversity guide us to an innovative ways and solutions.

\section{(Appendix A3.4)}

The Chart 1 synthetizes the four personnel management models found in the researched literature, showing the concepts, giving internal coherence and allowing characterize them as distinct theoretical models.

Chart 1 - Personnel Management Models and HR Action Guide Concepts

\begin{tabular}{|l|l|}
\hline \multicolumn{1}{|c|}{ Personnel Management Models } & \multicolumn{1}{c|}{ Concepts } \\
\hline Personnel Department & $\begin{array}{l}\text { 1. Labor Legislation } \\
\text { 2. Fordism-taylorism }\end{array}$ \\
\hline \multirow{2}{*}{ Human Behavior } & 1. Human Relations School \\
& 2. Behavioral Psychology \\
\hline Strategic & 1. Strategy \\
\hline Competency-based Approach & $\begin{array}{l}\text { 1. Competence } \\
\text { 2. Competitively Advantage }\end{array}$ \\
\hline
\end{tabular}

Source: done by the author based on the researched literature.

The guide concepts of each personnel management model, together with the adopted action content analysis to the human resource management will allow to classify the adopted actions in each one of the business groups belonged to the research.

\section{HUMAN RESOURCE MANAGEMENTS IN SUGAR-ETHANOL MILLS}

Thereby, the data collected analysis will be presented at the following order: closelyheld corporations, followed by the group that has shares on the BM\&FBOVESPA - São Paulo Stock Exchange, and then the international group which controls the mills.

\subsection{Personnel Management in Closely-held Corporations Mills}

In the closely-held mills, the human resources activities are distributed in four specialized sections, run by professionals called supervisors. These four sections are directly subordinated to the Board of Officiers, as presented in the Figure 1. 


\section{Figure 1. Human Resources Activities Organization}

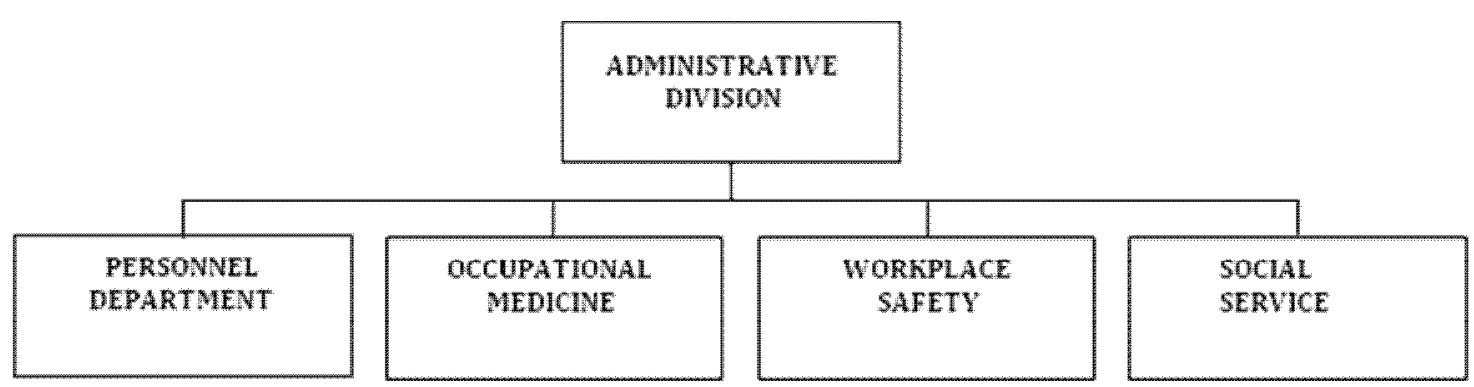

Source: Developed based on survey data (2012)

This model of organization, by specialized function, sounds that was created to attend a legal demand, because all the areas can be considered as legal demand.

The Personnel Department is run by the Personnel Department Supervisor, in charge of hiring routines, employees' frequency, wage paying, payroll taxes payment, vacation, etc., as well all the legal obligations. Besides the supervisor, there are other workers into personnel department auxiliary places.

The occupational medicine section is coordinated by an occupational medicine specialized physician, supported by nurses, also specialized. Such specialization is required by the Brazilian legislation.

The workplace safety section is run by a workplace safety specialist engineer. This professional can be supported by workplace safety supervisors. The Brazilian legislation defines the amount of professionals needed in this section.

The social service section is run by a social assistant. In one of the groups, the professional in charge for this section has familiar ties with the mill controller family, and this person responsibility is to handle the employees' social service, to control the benefits as well the social responsibility in the mills belonged to this group.

The existence of a social service area can also be understood as a legal requirement since the Law 4879/651 obligates the sugar-ethanol mills to allocate part of its revenue to the PAS - Social Assistance Plan - which must be prepared by a Social Service professional. Despite having the Social Service section, one of the groups does not have the PAS. In this specific group, the Social Service section is in charge of the Social Responsibility, which can be considered the only non-requirement legal one, but it cannot also considered a human resources activity.

This similar organizational way is replicated in each one of three mils controlled by this group. The actions developed and the organization way of human resource activities allow us classify the personnel management as Personnel Department, once the developed actions are categorized basically as the legal nature.

1This is a controversial legislation, because of this sector deregulation in the 1990s, the mils understood they did not have to allocate part of this revenue, once the Institute of Sugar and Ethanol IAA - Instituto do Açúcar e do Álcool - the organization in charge of supervise this law, had been extinct. However, some law suits already judged indicate that the mill still have to follow the legislation. 
In the second corporate group, also closely-held one, we found a configuration of the human resources attributions similar to the written before, with some variations into how the work is organized. One of then happens because in this group one of the three units centralizes the human resources activities, keeping in the other two units only the activities related to providing human resources services that are not possible be done at distance, such medical clinic, occupational safety, restaurant, and a small area to do a local work and then send this work to the main unit to perform the work as a whole.

Another variation identified was the existence of a Human Resources Section, tending to a functions organization. There were three HR sub-systems - recruiting/ selection, training/ development, and Personnel Management. The 2 firsts are coordinated by a single professional, who is not completely specialized yet. Further, the Personnel Management is coordinated directly by the professional in charge of the HR.

We found also a fairly organized personal training practice, with some actions focused on the labor formation that, according to the collected data, is hard to obtain due to the sugarcane mechanized harvest. There is also a scholarship program. Those actions, however, are not defined as personnel development policy, because both the training and scholarship participants are chosen by individual assessment, starting in the human resources and then sent to the board approval.

It indicates the adoption of a people management model as the personnel department one, but tending to the human behavior management model. This is because the transition to the other model depends on the human resources professional formation as well the existence of clearer policies to guide the actions of this area.

\subsection{Personnel Management in Publicly-held Mills}

The human resources in publicly-held sugar-ethanol mills is divided into six specific areas, or subsystems: development / communication / remuneration / recruiting and selection; legal; labor relations; restaurant; health and labor safety; and property security, as shown in the Figure 2 below:

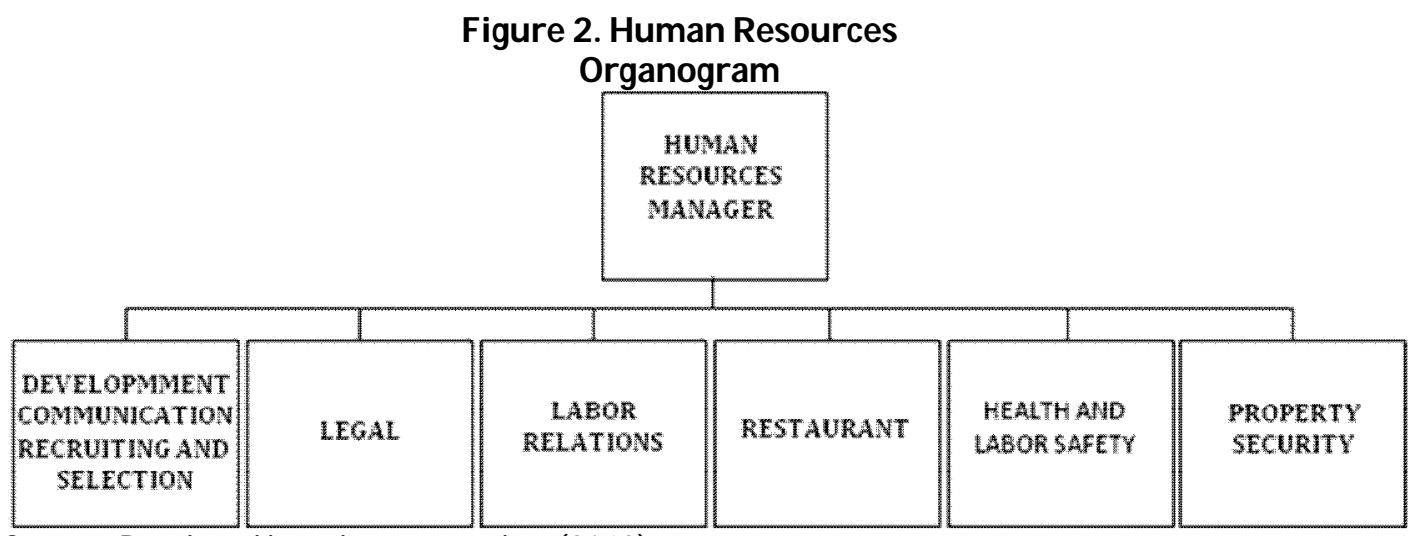

Source: Developed based on survey data (2012)

As can be seen in the organogram, the Human Resources Manager manages all the subsystems, where each one of them has a supervisor and other support workers. What can be seen as interesting in this system is the fact that the HR area is into one of the subsystems as staff and the fact that legal and patrimonial areas are also linked to the HR advisory services, functions which are not related to this area. 
The collected data show that this organization is relatively new and it was structured from the Human Resources Manager hiring because until then this group used to adopt a structure similar to the closely-held corporations ones.

It can be a strategy adopted to justify a manager-level professional hiring, generating, from this new manager, a department with a big number of workers - 204 in total - as Chart 2 shows.

\section{Chart 2 - Number of People Subordinated to the Human Resource Management}

\begin{tabular}{|l|c|c|c|c|c|c|c|}
\hline Unit & $\begin{array}{c}\text { Development, } \\
\text { Recruiting and } \\
\text { Selection } \\
\text { communication } \\
\text { Remuneration }\end{array}$ & $\begin{array}{c}\text { Labor } \\
\text { Relati } \\
\text { ons }\end{array}$ & Legal & $\begin{array}{c}\text { Restau } \\
\text { rant }\end{array}$ & $\begin{array}{c}\text { Property } \\
\text { Security }\end{array}$ & $\begin{array}{c}\text { Health } \\
\text { And } \\
\text { Labor } \\
\text { Safety }\end{array}$ & Total \\
\hline Headquarter & 06 & 07 & 06 & 27 & $43^{*}$ & 13 & 102 \\
\hline Unit 1 & 03 & 04 & 02 & 27 & $18^{*}$ & 7 & 61 \\
\hline Unit 2 & - & 04 & - & $17 * *$ & $13^{*}$ & 7 & 41 \\
\hline TOTAL & $\mathbf{0 9}$ & $\mathbf{1 5}$ & $\mathbf{0 8}$ & $\mathbf{7 1}$ & $\mathbf{7 4}$ & $\mathbf{2 7}$ & $\mathbf{2 0 4}$ \\
\hline
\end{tabular}

${ }^{*}=36$ are outsourced (matrix); 16 are outsourced (unit 1); in the unit 2 all workers are outsourced. ${ }^{* *}=$ 14 are outsourced. Source: Developed based on survey data (2012)

In this corporation group the headquarter unit is responsible to do the guidelines and standards related to the personnel management.

The human resource practices developed in this group are related to the legalnature actions, done by the Labor Relations (the name of this group's Personnel Department) and Labor Safety and Health. Besides the activities above, in this group the HR also develops $T \& D$, Recruiting and Selection, Communication, and Remuneration subsystems, which counts on specialized and adequately trained professionals to carry out these activities.

A concern about the internal communication was identified, which lead to a specific professional hiring to do this activity. The attributions of this professional are develop adequate communication tools to the employer/ employee relation. There is a specific training to improve this kind of communication using specific tools created to this specific purpose.

Regarding to the Training and Development actions, we verified that besides the technical training focused into training, expertise, and update the professionals of the group, behavioral nature activities are also focused on managers training and development. We verified also that the one of the most important concern in the HR area was the development of adequate behaviors in the workplace.

With this we found the evidences that allowed classify the personnel management model, in this corporation group, as human behavior management, once not only fulfill the legal nature attributions, but also do actions focused on a behavior development considered as appropriated by the company borders, consequently to the other workers, due to the adoption of a strategy that considers the border members training actions as multiplying factors over their subordinates.

\subsection{People Management in the Sugar-ethanol Mill Controlled by an International Group}

The human resource area organization in this corporation group presents double command: an administrative subordination to two executives who run the joint venture and 
a technical subordination to the international group corporative Human Resource Department.

Moreover, before the international group makes part of the group, the human resource area was formed by two people who were in charge of all mill activities. Actually, there is a department with six people divided into three human resource subsystems: Personnel Department; Recruiting and Selection; Development and Communication. The communication area was created just after the Agricultural Department creation, once the mill understood the necessity of establishing formal ways of communication with the rural area workers. This sector is being structured and it must be in the future another human resource subsystem. Following there is the Figure 3, which shows this mill adopted Human Resource Department configuration.

\section{Figure 3. - Sugar-ethanol Mill Organogram Controlled by an International Group}

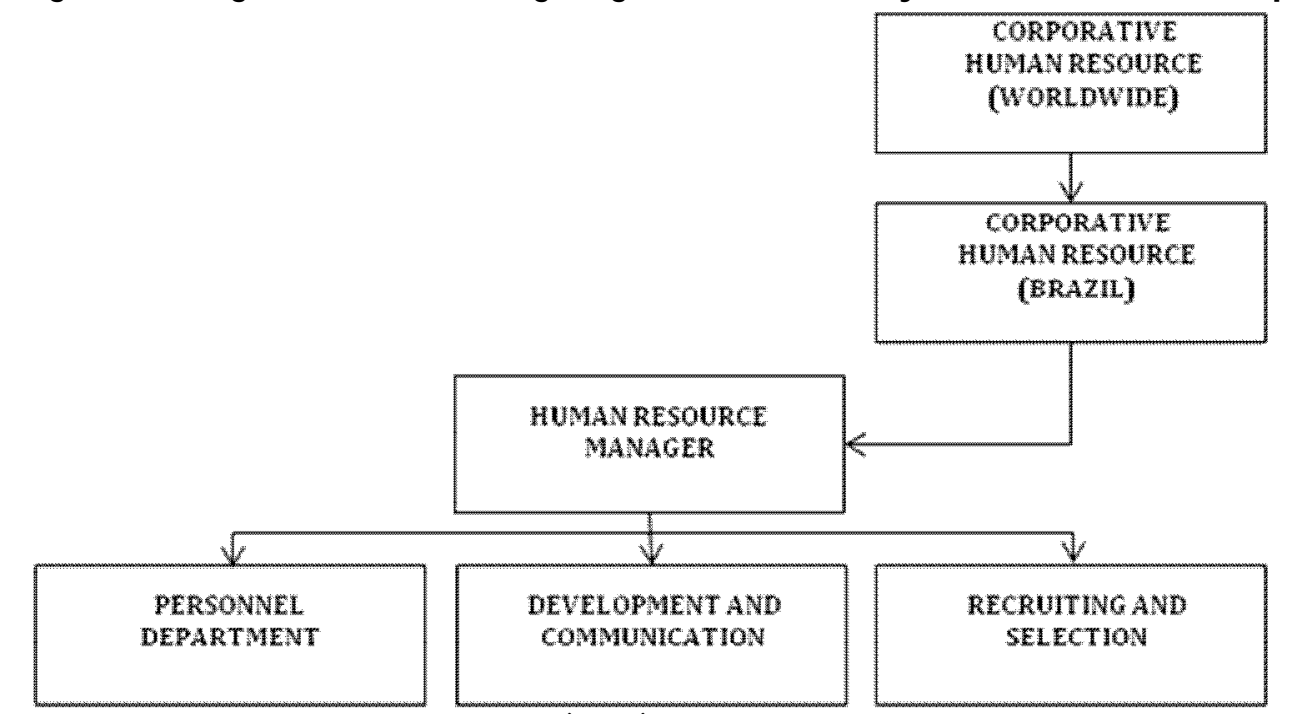

Source: Developed based on survey data (2012)

The Personnel Department takes care of all necessary routines to prepare the payroll; it calculates not only the payroll itself, but also the payroll taxes and all the Brazilian taxes required by the labor legislation. It is also in charge of this subsystem, the activities related to the job positions and their salaries, and following the labor relations. In this subsystem there are four workers.

The Recruiting and Selection subsystems are in charge of the activities related to the candidates' attraction and evaluation. There is a psychologist who counts to a specialized outsourced service to apply psychology tests for recruiting and to executive positions.

Developing and Communication are two activities grouped into a single subsystem, which responsibility is the personnel training and development actions and also the internal communication. There is a graduated psychologist in charge of these two activities.

The actions related to the communication were established from the Agricultural Department creation, a department with a big number of employees working directly in the sugarcane field distributed distantly from the industrial area. Although initially integrates the subsystem development, it must become an independent subsystem focused specifically on the internal communication.

Any professional, hired as an employee or a service provider, starts working in the mill only after a labor safety training, taught by the health safety staff and guided for this 
subsystem. This subsystem is not only in charge of this task, but also identifies personnel development opportunities to move forward to the mill. It can be done in professional formation activities to some positions considered critical, i.e., job places in which there is few labor supply, or to update, specialization and development of some workers in the mill.

Data collected show that besides a systemic organization developed into a human behavior management concept, the human resources policy are align to the international group, once the human resources manager has a double subordination: administratively this professional reports to the mill's board of officers, but technically reports to the international group HR. This area organizational way allows its fast readjustment to the organization strategies.

In this sense we identify that the mill Human Resources Department stands as the area in charge of identifying, hiring, and keeping the necessary human resources to attend the personnel demand in the group expansion projects in an economic sector, because before the joint venture formation, the controller group did not have this know-how.

This acting way allows classify the organizational model in the human resources area in this mill as strategic.

\section{Final considerations}

Considering the aim proposed - describe the personnel management practices, in mills with different shareholding control and identify the adopted personnel management model - a qualitative survey involving ten sugar-ethanol mills, controlled by three business groups, with different ways of corporate control: closely-held, publicly-held (BM\&FBOVESPA - Bolsa de Valores de São Paulo shares), and controlled by an international group.

The data analysis allowed notice that in one of the group, the closely-held one, which controls three sugar-ethanol mills, adopts the Personnel Department as the model of personnel management, once all actions in all sections are the legal nature, except the Benefits section, which occupation is the actions defined as social responsibility.

In the second corporate group, also a closely-held one, the human resources area has a similar configuration to the first one, adopting as the human resource management model the Personnel Department, tending to the human behavior management, because part of the staff is being formed yet.

Moreover, these two corporations groups data analysis showed that the people in charge of the human resources are subordinated to the General Management and they perform the tasks related to this area. We did not find any evidence that shows that these professionals are involved development of corporate strategies.

The third corporative group analyzed was the one that represented the mills with BM\&FBOVESPA publicly-held with the human resources area positioned as the border direction staff. The human resources area organization analysis shows that it is formed by 204 workers, part of it in the centralized unit, exerting the normative function to the other unities and it is in charge of executing the human resources processes to the headquarter. Besides, we could see areas outside the habitual ones belonged to the Human Resources, like the legal and property security, which can be understood as a strategy to increase the human resources advisory political weight and justify the managed status supported by the this advisory manager. The resources actions indicated the human behavior management model, as the human resource practices fundaments in this corporative group, because the developed actions content is based on behavioral psychology.

The sugar-ethanol mill controlled by an international group was represented, in this survey, by a joint venture formed in 2006, from a group of sugarcane producers and a big international corporation which did not have sugar and ethanol production know-how. The human resources practices analysis showed a systemic organization, where the Human 
Resources Manager is administratively subordinated to the mill general manager and technically to the international group human resources direction, allowing the alignment between the human resources and the group guideline actions. Besides, we found that this labor organization is into adjustment phase to fulfill to the group demands, which is in expansion phase in this business segment. This characteristic as well the human resources practices content analysis allowed us to classify this sugar-ethanol mill management model adopted as the strategic.

This path allowed us answer the question that guided our survey: Does the corporate control influence the people management into the sugar and ethanol mills? The collected data analysis showed that in the closely-held corporation group sugar-ethanol mills used as the survey subject the human resources area with a labor organization focused to meet the legal obligations, which allowed us classify it as Personnel Department management, the first model described in the second part of this article. Yet, the sugarethanol mills with shares trading at BOVESPA adopted the Human Behavior management, the second theoretical model described. Finally the sugar-ethanol mill controlled by an international group adopts the Strategic model of personnel management.

This may indicate that the stock control can be considered as one of the elements that differentiate the personnel management model used in the sugar-ethanol mills. However, this conclusion must be seen carefully, once this survey was done with only ten mills, in which only one was controlled by an international group. Hence to obtain a more effective answer to the formulated question other studies with a higher number of mills must be carried out.

\section{References}

Albuquerque, L. G.; Leite, N. R. P. (2009) Os Desafios De Gerir Pessoas Em Uma Estrutura Organizacional Remota. In; Rege - V. 16, P. 99-114.

Barbosa, L. (1999).Igualdade E Meritocracia: A Ética Do Desempenho Nas Sociedades Modernas. Rio De Janeiro: Fgv

Dejours, C. (1999). O Fator Humano. Rio De Janeiro: Fgv.

Dessler, G. (2003). Administração De Recursos Humanos. São Paulo: Prentice Hall.

Dutra, J. S. (2007) A Gestão De Pessoas Articulada Por Competências. In: T\&D - Inteligência Corporativa, V. 15, P. 20-21.

Eboli, M. (2002). O Desenvolvimento De Pessoas E A Educação Corporativa. In: Fleury, M. T. L. As Pessoas Na Organização. São Paulo: Gente.

Eisenstat, R. A. (1996). What Corporate Human Resources Brings To The Picnic: Four Models For Functional Management. In: Organizational Dynamics. V. 2, N.2. P. 7-22.

Enriquez, E. (2001). Interioridade Nas Organizações. In: Davel, E.; Vergara, S. C. Gestão Com Pessoas E Subjetividade.São Paulo: Atlas.

O Indivíduo Preso Na Armadilha Da Estrutura Estratégica. In: Mota, F. C. P.; Freitas, M. E. (2000). Vida Psíquica E Organização. Rio De Janeiro: Fgv.

Fleury, M. T. L. (2000). Gerenciando A Diversidade Cultural: Experiências De Empresas Brasileiras. In: Revista De Administração De Empresas- Rae, V.40. N. 3, P.18-25.

; Fleury, A.(2001).Construindo O Conceito De Competência. In: Rac - Revista De Administração Contemporânea, Edição Especial, P. 183-196.

Fischer, A. L. (2000). Um Resgate Conceitual E Histórico Dos Modelos De Gestão De Pessoas. In: Fleury, M. T. L. (Org.), As Pessoas Na Organização. São Paulo: Gente. 
; Albuquerque, L. G. (2005) Trends Of The Human Resources Management Model In Brazilian Companies: A Forecast According To Opinion Leaders From The Area. In: The International Journal Of Human Resources Management: Uk, V. 16, N.7, P. 1211-1227.

Franco, M. L. Análise De Conteúdo. São Paulo: Liber, 2005.

Fundação Pró-Cana (2012). Anuário Da Cana 2011. Ribeirão Preto: Fundação Pró-Cana.

Hampton, D. R. (1992) Administração Contemporânea. São Paulo: Makron.

Harvey, D. (2000) A Condição Pós-Moderna.São Paulo: Loyola.

Herzberg, F. (1997). Mais Uma Vez: Como Motivar Seus Empregados. In: Gestão De Pessoas, Não De Pessoal. Rio De Janeiro: Campus.

Igalens, J. (1999). Cent Ans De Gestion Du Travail. In: Revue Française De Gestion, N.126, P.5-11. Junqueira, F. (2005). O Rh Que Dá Lucro. Rio De Janeiro: Qualitymark.

Le Boterf, G. (2003). Desenvolvendo A Competência Dos Profissionais. Porto Alegre: Artmed.

Mcgregor, D. (1999). O Lado Humano Da Empresa. São Paulo: Martins Fontes.

Milkovich, G.; Boudreau, J. W. (2000). Administração De Recursos Humanos. São Paulo: Atlas.

Muritiba, At Al. (2012) Challenges For Brazilian Mncs' International Human Resources Management. In: European Journal Of Management, V. 6, P. 248-264.

Mintzbrg, H. (2003). Criando Organizações Eficazes. São Paulo: Atlas.

Nascimento, A. M. (2003) Curso De Direito Do Trabalho. São Paulo: Saraiva.

Orlickas, E. (2001). Consultoria Interna De Recursos Humanos. São Paulo: Futura.

Porter, M. (2003). O Que É Estratégia. In: Ulrich, D. (Org.), Recursos Humanos Estratégicos.São Paulo: Futura.

Prahalad, C. K.; Hamel, (2003). G. A Competência Essencial Da Organização. In: Ulrich, D. (Org.), Recursos Humanos Estratégicos.São Paulo: Futura.

Reis, G. G.; Tonelli, M. J.; Fleury, M. T. L. (2012) Human Resources Management In Brazilian Multinationals. In: Journal Of Management And Entrepreneurship, V. 5, P. 17-29.

Santos, B. De S. (2000). Da Idéia De Universidade À Universidade De Idéias. In: Santos, B. De S. Pela Mão De Alice: O Social E O Político Na Pós-Modernidade. São Paulo: Cortez.

Silva, S. M.; Fleury, M. T. L. (2005) A Gestão Das Competências Organizacionais Na Perspectiva Da Cadeia Produtiva: Um Estudo Na Indústria De Telecomunicações. In: Rausp, V. 40, N. 3, P. 253-265. Taylor, F. W. (1995). Princípios Da Administração Científica. São Paulo: Atlas.

Thévenet, M. (1999). Lê Retour Du Travail Et La Fin De La Gestion Dês Ressources Humaines. In: Paris: Revue Française De Gestion, Numéro Spécial.

Tonelli, M. J. Et Al. (2002). Desenvolvimento Histórico Do Rh No Brasil E No Mundo. In: Boog, Gustavo; Boog, Madalena (Org.), Manual De Gestão De Pessoas E Equipes: Estratégias E Tendências. V. I, São Paulo: Gente.

Zarifian, P. (2001). Objetivo Competência: Por Uma Nova Lógica. São Paulo: Atlas. . (2003). O Modelo Da Competência: Trajetória Histórica, Desafios Atuais E Propostas. São Paulo: Senac.

Appendix on line at the journal Website:

Revista Galega de Economia/ Economic Review of Galicia: ttps:/ / ideas.repec.org/ s/ sdo/ regaec.html http:/ / www.usc.es/ econo/ RGE/ benvidag.htm 


\section{Appendix}

\section{A3.1. The First Personnel Management Model: Personnel Department}

The literature records the personnel department existence in the companies since mid XIX century, in the European banks (IGALENS, 1999). However, as a wide spread practice, most authors cited the 1920s as reference to the consolidation of the first personnel department model.

That period was characterized by an intense social moving leading to establish laws to guide the relationships between the company and its workers and culminated, in the end of the War I, with the foundation of the International Labor Organization - ILO - entity linked primarily to the United Nations, which encouraged its members to create specific laws to guideline the labor relations.

Not only the workers but also the different social actors criticized the labor conditions and have engaged to establish legal principles to regulate the labor relationships within the capitalist companies. Entrepreneurs like Robert Owen ${ }^{2}$ in England and even the Catholic Church condemned the labor conditions in companies in that time, to the point that in 1891 the Pope Leo XIII edits the Encyclical letter Rerum Novarum with harsh critics to the labor organization within the business organization.

In this concept, some sparse laws are edited focusing limit the labor contract, but experts in labor law find that the Mexican Constitution in 1917, the Weimar Republic in 1919 in Germany, and the Carta Del Lavoro in Italy in 1927 were the first ones which included clearly the legal principles regarding to the labor relations regulation (NASCIMENTO, 2003).

In this sense, the labor legislation is the one which, from 1920, pressures the companies to create a specific area to nurture the relations with their workers. It explains the name given to this model, by Fisher (2002), "Personnel Department", in which the action is centered on compliance.

Into the historic context, in this same time, the Scientific Administration (TAYLOR, [1911] 1995) development and dissemination occurs which, using the labor analysis together with the time and motion study, triggers a deep revolution in the labor concept that, according to Barbosa (1999, p.109), at the first time there was a possibility of managing the human and material resources in a scientific way.

Taylor (1995) when suggests the design of positions, withdraws from the worker the reflexive action about the work, establishing the workers training necessity to each position tasks, indicates the training and scientific selection of each worker necessity to occupy their positions as workers, besides establish bonus payment on production. These proposals contributed to create the first set of activities that, gradually, would make part of the human resources area functions.

2Utopic socialist. He is considered the father of the cooperative movement. From a humble origin, he ends up owing a big company in Scotland. There, he reduced the labor hours to $10.5 \mathrm{~h}$ per day, ordered built home to the workers, as well the first kindergarten and the first cooperative. In 1817 he evolves from the charity work to the frontal critic to the capitalism. He founded in the USA a socialist colony called New Harmony. 
Thus, besides the activities related to the legal requirements compliance, select, train, and pay the works start to be part of the personnel department duties (TONELLI et al., 2002).

This way, the contours of an organization is outlined in which are established, as a response to the emergence of laws that regulate the labor relationships in the companies that, associated to the normative and prescriptive science conception of the taylorists ideas, can explain other denominations such as "Industrial Model" (MLKOVICH and BOUDREAU, 2000) and "Hierarchical Model" (EISENSTAT, 1996).

The work conception that underlies this model is explained by Zarifian (2001, p.37) as a group of elementary activities of a matter transformation able to aim, analyze, rationalize, organize, and impose in the workshops. At that time the activities are human body gestures.

Thereby the taylorist-fordist principles, associated to the legal requirements, characterize the Personnel Department actions as personnel-control activities because both the law and the Scientific Administration fundaments have in control one of their basal elements.

Besides some disagreements among the authors regarding the period that categorizes this form of organization in the human resources area, there is a consensus that surveys carried out from 1927 to 1932 by Elton Mayo at Western Electric in Chicago mean not only a change in the personnel management way but also lays the new way of organization groundwork of this activity in the companies.

\section{A3.2. The Second Personnel Management Model: Human Behavior.}

The Human Relation School ideas diffusion paves the way to the treatment of work disorders and turns its attention to an informal group existence, to the communication processes, the motivation, and also the leadership (BARBOSA, 1999).

However, yet, the external environment influences and contributes to expand this function activities. During the Great Depression in the 30s, there is a reduction in the importance to the companies human resources activity (MLKOVICH \& BOUDREAU, 2000), but when there is an economic growth resumption the unions start to move greatly, leading the companies seek trading skilled professionals creating this way a new activity called Industrial Relations. Besides, during the World War II, its effort made unfeasible the salaries increase. This way, the companies begin to provide indirect benefits, which also need specialized professionals to manage such activity.

Thereby, the personnel department - or industry relations department to some organizations - activities are extended to the following set of attributions: personnel management (is in charge of the procedural aspects required by law), recruiting and selection, training, remuneration, union relations, and benefits.

The new element is the Human Relations School ideas inclusion, denominating this model as "Human Behavior" (FISHER, 2002), while the activities increase - Industrial Relations and Benefits - which characterize this period, allow denominate it as "Function Expansion" (IGALENS, 1999), or also "Professional Model” (EISENSTAT, 1996).

From the theoretical point of view, the great innovation is the use of concepts from the human sciences which raises the question about the economic man who guided the taylorism-fordism theoretical premises introducing the idea of social man or, as explained by Dejours (1999, p. 33), 
here is the work world which is reduced to the intersubjective and social world. The physical environment and the work place demands specificity, as well the activities, in the ergonomic sense of the term, are excluded from the analysis. [...]. Regarding to the organizations psychosociology, it considers the work environment only as a concept, decorative, without any direct impact in the organization of the human behavior.

However, although the debate around the human being concept, the authors linked to the Human Relations School to adopt the same conception of work of the anterior model. The solution found to the work malfunctions is the "work rotation", i.e., the workers should change periodically their work positions as a solution to the repetitive, monotonous, and meaningless work.

It is about a period that can be characterized as the function stabilization (IGALENS, 1999), as the Human Relations School original concepts consolidation, specially the behavioral psychology ones.

In the theoretical context, there is an intense debate among the authors linked to the Human Relations School, who try to demonstrate clearly the differences between this personnel management and the anterior. McGregor (1999), when built the X and Y Theories presents arguments that show the differences between the models, in which the Theory X represents the taylorist concept and the Theory $\mathrm{Y}$ is based on the Human Relations School and the Behavioral Theory.

In the organizational practice occurs the incorporation of the people management concept, which uses these ideas as a theoretical reference, when associated to the new functions incorporated by the anterior model, it transforms this area in a space formed by professionals from different backgrounds and, consequently, proliferates new technologies from several origins. From this environment comes out the denomination Human Resources Administration, with specialized and technologies more and more sophisticated to manage people.

This leads to an organizational way with several subsystems, each one responsible for executing the relationship policies between the company and its workers. The activities are still the same as the anterior model, changing only the training area, which incorporates the personnel development conception, i.e., the personnel management (it is in charge of the procedural aspects required by the legislation); recruiting and selection; training and development; remuneration, union relations; and benefits.

Thus, we can understand the existence of several human resources subsystems, frequently cited in the textbooks (DESSLER, 2003), each one responsible by conducting part of the activities which must underline the company-worker relation. Obviously this systemic organization prescription contributes to the creation and dissemination of specific techniques to each subsystem, as strategy, even though to justify its existence. However, as explained by Orlickas (2001, p.30), the human resources management critical point is identified in this stage: the people [...] they are administrated technically and managed in parts. That is the reason this set of techniques start to lose the relation to the work, [...] it begins to lose functionality and operability, which can be considered as a favorable context for the emergence of a new Human Resources Management. 


\section{A3.3. The Third Personnel Management Model: Strategic}

In the external environment there are signs of change and in the organization scope we can verify a reduction of productivity in the companies which follow the taylorist-fordist rationalization principles. There is a significant increase of competition between the countries for new markets, especially Japan and the European countries, yet recovered by the Second War (TONELLI et al., 2002).

The productivity decrease and the competitiveness increase factors induce two reactions that echo both in the companies and in the theoretical debate. The companies seek to look to the competitors, specially the Japan, to try to understand their managing way. The organizational study specialists seek alternatives to overcome the productivity reduction and increase the companies' competitively.

This crisis set the beginning of a fast changing period, fluidity and uncertainty (HARVEY, 2000). In the theoretic context, the external environment perception indicates the new references necessity which must guide the management models. Thus the strategy notion is included (PORTER, 1996) as a constitutive element of a new human resources management model.

In the organizations, regarding to the personnel management, is pointed out the necessity of link the human resources strategies to the companies ones. The borders' answers to the human resources area are closer ties among the other functional areas, putting themselves in a provider position contributing to reach the organizational goals. It allows understand the denomination "Partnership", attributed by Eisenstat (1996). But the strategy notion inclusion indicates the theoretical references which underlie this model change, allowing also called "Strategic" (FISHER, 2002), indicating that the human resources management policies and practices come from organizational strategies. From this model the HR textbooks arise, indicating that the human resources area must be considered as the profit center area (JUNQUEIRA, 2005).

The concept of work remains as the same the anterior models which guided the personnel managing area organization described before, the work dysfunctions contribution is the enrichment of positions, as alternative to the repetitive, monotonous and meaningless work, using as a theoretical matrix the taylorist notion of draw of positions. This technic suggested by Herzberg (1997) comes out from motivation surveys, leading to the Two Factors Theory development.

It is a factor in which the company, to reach its goals, is presented as almighty and installs the certainty to offer to the worker, at the same time, a statute and a adequate role to its dynamism and submission, and an intellectual and behavioral knowledge which encourages the domain of both him/herself and the things, as well the circumstances adapting. Doing it, according to Enriquez (2001, p. 21), it tends to childish the worker, whatever claims otherwise.

\section{A3.4. The Fourth Personnel Management Model: Competency-based Approach}

The fourth human resources area organization basic features begin to set on two fronts: the debate between specialists and the companies. In the first, the attempt is to build a new model based on the strategy notion with the purpose of creating more flexible management able to absorb fast changes, the external environment fluidity and uncertainties. In the second, the fragmented structure predominant in the anterior model and the introduction of a decentralization process from the human resources functions to the line managers. 
In the theoretical context, the strategy notion, which according to Porter (2003, p.111), being different, is linked to the competitive advantage that, according Prahalad \& Hamel (2003, p.59), are surrounding individuals whose efforts are not narrowly focused, to this people recognize the opportunities to combine their technical capacities with the others from new and interesting ways. In this case, as explained by Barbosa (1999, p.125),

It is about you take the difference as a competitive advantage. It implies in built intentionally a differentiated organization in human resources terms, with individuals from different ethnic religious, geographic, and intellectual origins to this diversity guide us to an innovative ways and solutions.

This interpretation allows us understand the valorization of characteristics, like the institution, the knowledge, and the creativity as the workers' personal attributes, frequently cited as compounds in this fourth human resources managing model and, also, in the culture concept reinterpretation origin in the organizational studies, which is now understand also as diversity (FLEURY, 2000).

The conception of strategy as competitive advantage is associated also to the notion of essential competences, interwoven in the human resources area the individual competence idea.

In turn, this notion presupposes the necessity of thinking in an organizational way, in which the work, as shows Santos (2000, p.196), was firstly [understood as] the performance of physical force in handling the means of production, became also an intellectual and qualified work, as a result of a prolonged action. Or, as explained by Zarifian (2001, p.56), the work itself is no longer an objectifiable, standardizable, or prescriptive data, which would be simply reduced to a tasks list [...] it becomes a personal competency direct elongating in which an individual mobilizes facing a professional situation.

This understanding indicates the work conception reframing, being understood as an imagination act. It indicates the possibility of rupture with an organization way built around the work places concept, standardization and places prescription, based on taylorist principles and opening the possibility of use as premise of competency idea, foreseen the work return to the worker (Zarifian, 2003; Thévenet, 1999).

At this point there is a necessity of thinking over about the competency notion, frequently lead to a number of misunderstandings.

In the researched literature there are two references around the competency notion debate: in the United States, in 1973, with the publication of "Testing for competence rather than intelligence" article by McClelland and in France, at the same decade, inquiring the qualification and the professional formation process notions. These facts characterized this theme introduction into the organizational studies (FLEURY \& FLEURY, 2001; ZARIFIAN, 2001).

Initially, the American literature differentiates skill, ability, and knowledge competencies, defining competency as someone's characteristic related to a superior performance on a task. In this sense the reference that balances this notion is the task or the set of tasks relevant to a position. Only in a second moment they recognize that work with a set of defined abilities and requirements from the design of positions, a taylorist characteristic, no longer meets the complex, mutable, and inserted demands in a globalized world. 
Differently, the French debate springs from the dissatisfaction between the professional formation and the work world necessities, searching alternative to bring close the professional teaching to the real necessities.

Mutations happened in the contemporaneous society work content are analyzed a new logic in the work organization is identified (ZARIFIAN, 2001).

In the same period, the organizational studies indicate the external factors, like the consumers behavior changes, the competitiveness, and the new technologies, as a driver force in the organizational change processes (FISHER, 2002) creating this way the conditions to emerge new organizational structures (cells, teams, and nets) differently from the taylorism-fordism ones.

This new structural settings demand a worker able to learn, therefore, different that one who was conceived from the Scientific Administration (TAYLOR, 1995), which aimed eliminate the random, the guesswork, and the individual style in the way of executing the activity. Taylor has sought the best way to performance a task, i.e., he has looked for universal procedures that were for all (BARBOSA, 1999). In this concept, a product production is nothing but these elementary operations chaining according to a logical sequence. Thus, what is called work productivity is nothing but the work speed and the resulting production flow organization, minimizing the work time in each unity of goods (ZARIFIAN, 2001).

The new work organization configuration calls for a worker with a different profile from the one shaped based on the task notion. With this, the two actual models counterbalance: the work place and the occupation (ZARIFIAN, 2003). The last one, called professional, according to Le Boterf (2003, p.37), is the one who knows how to manage a complex professional situation, to this, the following basic competencies must be present: acting in a pertinent way; know how to mobilize knowing and knowledge in a professional context; know how to integrate or combine multiple and heterogeneous knowledge; know how to transpose; know how to learn and learn to learn; and know how to engage.

This way the notion of competence that emerges in the organizational studies as an answer to the changes caused by the productive organizations external environment, is due to a perception that indicates the necessity of a new work organization adoption which can be considered as a competitive strategy.

This new environment calls for a worker able to mobilize knowledge and expertise, in a professional situation, to face known and unknown events and after solving them reflect about how to understand them, generating this way new knowledge. This requires the development of the capacity to take the initiative and to assume the responsibility over the professional situations faced. It is to possess a practical intelligence of the situations, being based on the acquired knowledge and then transform them as the diversity increases. It is be able to mobilize the actors net around the same situations and take over responsibility areas, no longer specific and transcript tasks (ZARIFIAN, 2003).

The work management with this conception is into the origin called qualifying organization, or organizational learning, in which the human resources area activities remain the same as the anterior configuration. Here, again, the training and development activities are the ones that suffer significant alterations, incorporate the concept of corporative education instead of training. In some corporations this activity is called Corporative University (EBOLI, 2002). This way, into this new work organization we can find the following activities: personnel management (takes care of the procedural aspects required 
by law); recruiting and selection; personnel development and education (corporative university); remuneration; union relations; and benefits.

In the corporate practice, there is a Human Resources Department reorganization redefining the worker's profile, who ceases being a expertise in one of the subsystems and becomes a human resources generalist, called Line Personnel Officer - LPO - or human resources internal consultant, whose the main activity is provide advice to the other functional departments managers (ORLICKAS, 2001).

In this way of organization the human resources competency is to establish the people management policies and strategies which must be transformed into management daily practices by the ones who occupy the manager position whose shall, besides their attributions, execute some other attributions before centralized in the human resources, indicating this way a decentralization movement towards the human resources actions.

This people management model represents the previous model support theoretical references displacement, using now the strategy theories to establish coherent relations among its constitutive elements. There is also a work conception reinterpretation which is now understand in a different way from the one established by the consolidated by the taylorism-fordism.

This reference changing also changes the human being comprehension. Now it is no longer the Scientific Administration economic man, neither the social - from the Human Relations School - or yet the organizational one, but as pointed out by Fisher (2002, p.32), today, the human being role at work has being transformed, and his/ her human characteristics like knowing, intuition, and creativity have being valorized.

This way of organizing the work is characterized also by the Personnel Management denomination change in which, as explained by Fisher (2002, p.32), tries to emphasize the character of action - management and its attention focus: the people. Although the administration and management are used as synonym, however, in a general way, management is considered an action in which the outcome of the process to be managed with a lower degree of predictability.

Revista Galega de Economia/ Economic Review of Galicia: ttps:/ / ideas.repec.org/ s/ sdo/ regaec.html http:/ / www.usc.es/ econo/ RGE/ benvidag.htm 